\title{
International
}

Journal of Thysical

ofducation

DOI : 10.15740/HAS/IJPE/8.1/36-39

e ISSN-0976-7924 ■ Visit us : www.researchjournal.co.in

Research Paper

Volume 8 | Issue 1 | April, 2015 | 36-39

\section{Self-esteem levels of slum young women and their talents and performance in extracurricular activities}

\author{
MUGDHA DESHPANDE ${ }^{1}$ AND DESETTY RAMANAMMA
}

Received : 09.12.2014; Revised : 06.03.2015; Accepted : 19.03.2015

Members of the Research Forum

Associated Authors:

'Department of Human Development and Family Studies, College of Home Science, Vasantrao Naik Marathwada Krishi Vidyapeeth, PARBHANI (M.S.) INDIA

Author for correspondence : DESETTY RAMANAMMA Department of Human Development and Family Studies, College of Home Science, Vasantrao Naik Marathwada Krishi Vidyapeeth, PARBHANI (M.S.) INDIA

Email:manraman_02@rediffmail. com

\section{-ABSTRACT}

Two hundred slum young women was chosen at random from the 10 slum areas of Parbhani town of Marathwada region of Maharashtra state. Out of which 30 were from the middle SES group and the remaining 170 were from the low SES group. The age group of the slum young women ranged between 20yrs and 25yrs. The Self-esteem Scale for Women developed by Kapadia and Verma was administered on them for assessing their self-esteem levels. Kuppuswamy's socio-economic status scale for urban population revised by Patnam (2010) was used to assess the socio-economic status of sample slum young women. The results reveal that majority (57\%) of the selected slum young women were assessed to have low self-esteem level followed by medium level of selfesteem (29\%) and high level of self-esteem (13\%) irrespective of their low and middle SES groups. Family background variables such as family size, family type, age and education of fathers and mothers were found to have significant influence on their self-esteem levels. Results reveal that that all the selected slum young women having high self-esteem level were found to have special talents in many of theareas as compared to their counterparts having medium and low levels of selfesteem. Irrespective of self-esteem levels of slum young women $(48 \%, 49 \%, 85 \%)$ significantly a higher percentage of them reported that their involvement in extracurricular activities was poor.

- KEY WORDS : Self-esteem, Slum young women, Extracurricular activities, Talents

- HOW TO CITE THIS PAPER : Deshpande, Mugdha and Ramanamma, Desetty (2015). Self-esteem levels of slum young women and their talents and performance in extracurricular activities. Internat. J. Phy. $E d u ., 8$ (1) : 36-39. 